\title{
A highly selective fluorescent probe for hydrogen peroxide and its
}

\section{applications in living cells}

Zhiyuan Zhuang,Qian Yang, Zhanming Zhang,Qilong Zhang, Gengxiu Zheng,Fuxu Zhan*

School of Chemistry and Chemical Engineering, University of Jinan, Jinan, Shandong 250022, P.R. China.

*Corresponding Author.

Tel: +86-53182765841.

E-mail address: chm_zhanfx@ujn.edu.cn.

\begin{abstract}
A turn-on fluorescent probe $\mathbf{A C R}\{6$ '-[2-(azidomethyl)benzoyl]-7'-chloro- $N, N$-diethylrhodol $\}$ for selective detection of $\mathrm{H}_{2} \mathrm{O}_{2}$ was developed.An ester bond was broken by the nucleophilic substitution of $\mathrm{H}_{2} \mathrm{O}_{2}$ which releasedstrong fluorescence. Probe ACR was proved to be made up of three essential parts, chlorine atom, azide group and an active carbonyl.This probe showed high selectivity for $\mathrm{H}_{2} \mathrm{O}_{2}$ and a linear fluorescence intensity enhancement with a wide range of concentrations of $\mathrm{H}_{2} \mathrm{O}_{2}$. Fluorescence imaging experiments in HeLa cells indicated its potential to image $\mathrm{H}_{2} \mathrm{O}_{2}$ in biological systems.
\end{abstract}

\section{Keywords}

Hydrogen peroxide, Selective detection, Fluorescent probe 


\section{Introduction}

Hydrogen peroxide $\left(\mathrm{H}_{2} \mathrm{O}_{2}\right)$, a precursor molecule of other reactive oxygen species (ROS) [1],plays a crucial role in many biological processes in the human body, such as respiration[2], intracellular signaling[3], and immune responses[4-5]. However, over production of $\mathrm{H}_{2} \mathrm{O}_{2}$ may cause many diseases, such as neurodegenerativediseases [6], inflammatory diseases [7], Alzheimer's diseases [8] and cancers[9]. Therefore, it is necessary to develop sensitive and selective methods for the detection of $\mathrm{H}_{2} \mathrm{O}_{2}$ in living systems.

Currently, many chemical tools have been developed to detect intracellular $\mathrm{H}_{2} \mathrm{O}_{2}$, such as mass probes[10], proteomics probes[11], and fluorescent probes[12,13]. Among these methods, fluorescence methods have gained a lot of attentiondue to their fast response, high sensitivity, and ability to afford high spatial resolution through microscopic imaging[14]. In consequence, various fluorescent probes have been developed and applied for $\mathrm{H}_{2} \mathrm{O}_{2}$ analysis for the past few years[12-13,15-31]. Meanwhile, several unique $\mathrm{H}_{2} \mathrm{O}_{2}$-responsive sites were developed, such as boronate [12,15-18], arylsulfonyl esters [19,20],diphenylphosphine [21],a-diketone groups [22-25], metal complexes [26-29] and chalcogen [30,31].Although some of these probes have permitted the detection and quantification of intracellular $\mathrm{H}_{2} \mathrm{O}_{2}$, such probe systems lack full applicability to biological systems due to their modest selectivity, requirements for external enzymes or incompatibility with biological milieus [28]. So it is especially important to develop high-selectivity probes to monitor the $\mathrm{H}_{2} \mathrm{O}_{2}$ in the biological process.

\section{Experimental}

\subsection{Materials and instruments}

Fluorescence spectra were carried out on an Edinburgh Instruments Ltd-FLS920 fluorescence 
spectrophotometer. UV/vis spectra were made with a Shimadzu UV-2600 spectrophotometer.All reagents and solvents were purchased from commercial suppliers and used without further purification unless otherwise stated. Deionized water was used throughout all experiments. All reactions were magnetically stirred and monitored by thin layer chromatography (TLC). Column chromatography was performed using 200-300 mesh silica gel supplied by Qingdao Marine Chemical Factor. The ${ }^{1} \mathrm{H}$ NMR and ${ }^{13} \mathrm{C}$ NMR spectra were recorded on a Bruker AVANCE 400 at 400 and $100 \mathrm{MHz}$, respectively. All NMR chemical shifts were referenced to residual solvent peaks or to $\mathrm{Si}\left(\mathrm{CH}_{3}\right)_{4}$ as an internal standard.NMR spectra were recorded in $\mathrm{CDCl}_{3}$ orDMSO- $d 6$. Chemical shifts were referenced to residual $\mathrm{CHCl}_{3}$ at $7.26 \mathrm{ppm}$ for ${ }^{1} \mathrm{H}$ or $77.0 \mathrm{ppm}$ for ${ }^{13} \mathrm{C}$. All coupling constants $J$ are quoted in Hz. FTIR spectra were obtained with a Bruker Vertex 70 FT-IR spectrometer with $\mathrm{KBr}$ pellets. All IR samples were prepared as thin film and reported in wave numbers $\left(\mathrm{cm}^{-1}\right)$. High resolution mass spectra were obtained on a Q-TOF6510 instrument mass spectrometer.

\subsection{Synthesis}

Synthesis of 7'-chloro- $N, N$-diethylrhodol<smiles>CCN(CC)c1ccc(C(=O)c2ccccc2C(=O)O)c(O)c1</smiles>

To a suspension of 2-(4-diethylamino-2-hydroxybenzoyl)benzoylacid (6.0 g, $19.1 \mathrm{mmol}$ ) and resorcinol (2.1 g, $19.1 \mathrm{mmol})$ in trifluoroacetic acid (TFA,20 mL) in a sealing tube, was added molecular sieve (2.0 g). The resulting mixture was heated to $90{ }^{\circ} \mathrm{C}$ and stirred for $6 \mathrm{~h}$. Then the mixture was cooled to room temperature and concentrated to yield a crude product, which was 
recrystallized in a mixture ofethyl acetateand petroleum $(\mathrm{V}: \mathrm{V}=1: 1)$ affording 7'-chloro- $N, N$-diethylrhodol as $\quad$ a $\quad$ red $\quad$ solid $\quad(6.8$ g, $84.5 \%$ yield $) . \quad$ Data for 7'-chloro- $N, N$-diethylrhodol: $\mathrm{R}_{f} 0.35$ (petroleum ether:ethyl acetate $\left.=1: 1\right) ;{ }^{1} \mathrm{H}$ NMR $(400 \mathrm{MHz}$, DMSO-$\left._{d 6}\right) \delta 8.07(\mathrm{~d}, \mathrm{~J}=6.8 \mathrm{~Hz}, 1 \mathrm{H}), 7.56-7.58(\mathrm{~m}, 2 \mathrm{H}), 7.17(\mathrm{dd}, J=6.8,1.6 \mathrm{~Hz}, 1 \mathrm{H}), 6.86(\mathrm{~s}$, 1H), $6.77(\mathrm{~d}, J=9.6 \mathrm{~Hz}, 1 \mathrm{H}), 6.71(\mathrm{~d}, J=6.8 \mathrm{~Hz}, 1 \mathrm{H}), 6.70$ (s, 1H), 6.36 (s, 1H), 3.47 (q, $J=6.8$ $\mathrm{Hz}, 4 \mathrm{H}), 1.13(\mathrm{t}, J=6.8 \mathrm{~Hz}, 6 \mathrm{H})$; HRMS-ESI $(\mathrm{m} / \mathrm{z})[\mathrm{M}+\mathrm{H}]+$ calcd forC ${ }_{24} \mathrm{H}_{21} \mathrm{ClNO}_{4}{ }^{+}, 422.1154$, found: $422.1151 ; \mathrm{mp} 177.9 \sim 179.5^{\circ} \mathrm{C}$.

Synthesis of ACR
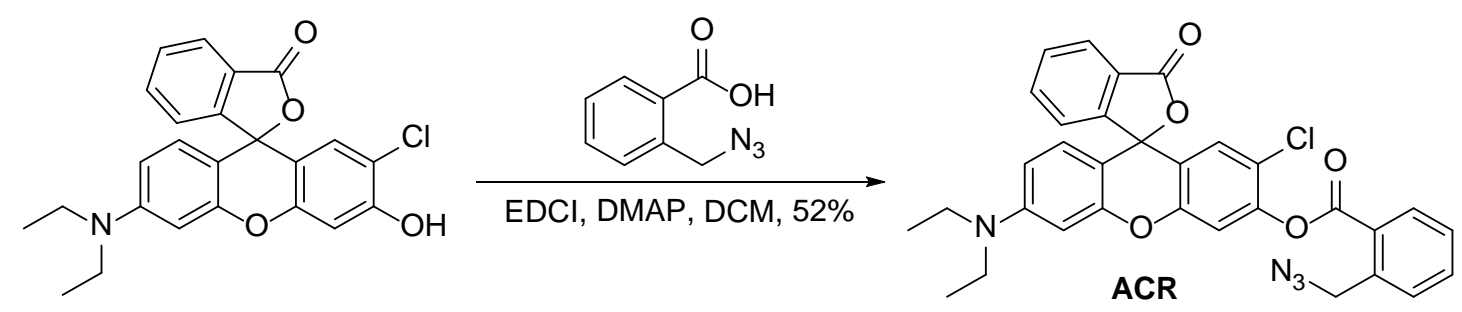

A solution of 2-(azidomethyl)benzoyl acid (252.2 mg, $1.4 \mathrm{mmol})$ in DCM (5 mL), was added 1-Ethyl-3-(3-dimethylaminopropyl)carbodiimide hydrochloride (EDCI,341.5 mg, 1.8mmol), 4-dimethylaminopyridine (DMAP,72.5 mg, $0.59 \mathrm{mmol}$ ) and 7'-chloro- $N, N$-diethylrhodol (500.0 $\mathrm{mg}, 1.19 \mathrm{mmol})$. The resulting mixture was warmed to room temperature and stirred for $12 \mathrm{~h}$. The resulting solution was poured into water $(30 \mathrm{~mL})$ and extracted with DCM $(3 \times 20 \mathrm{~mL})$. Combined organic layers were washed with brine, dried over anhydrous $\mathrm{MgSO}_{4}$ and concentrated to afford red oil. Flash chromatography of the crude product (5:1 petroleum ether:ethyl acetate) provided the desired product as a colorless oil (358.81 mg, 52\%). Data for ACR: $\mathrm{R}_{f} 0.35$ (petroleum ether:ethyl acetate = 5:1); ${ }^{1} \mathrm{H}$ NMR $\left(400 \mathrm{MHz}, \mathrm{CDCl}_{3}\right){ }^{1} \mathrm{H}$ NMR $\left(400 \mathrm{MHz}, \mathrm{CDCl}_{3}\right) \delta 8.36(\mathrm{dt}, J=$ 9.2, 4.6 Hz, 1H), 8.07 (d, $J=7.5 \mathrm{~Hz}, 1 \mathrm{H}), 7.74$ (tt, $J=4.1,2.0 \mathrm{~Hz}, 1 \mathrm{H}), 7.71-7.69$ (m, 1H), 7.69 - 7.65 (m, 1H), 7.63 (d, $J=7.2 \mathrm{~Hz}, 1 \mathrm{H}), 7.60-7.52$ (m, 1H), 7.28 (d, $J=3.4 \mathrm{~Hz}, 2 \mathrm{H}), 6.90$ (s, 1H), 6.60 (d, $J=8.9 \mathrm{~Hz}, 1 \mathrm{H}), 6.47$ (d, $J=2.5 \mathrm{~Hz}, 1 \mathrm{H}), 6.41$ (dd, $J=9.0,2.6 \mathrm{~Hz}, 1 \mathrm{H}), 4.99-4.75$ (m, 2H), $3.46-3.18$ (m, 3H), $1.24-1.10$ (m, 6H); $\left.{ }^{13} \mathrm{C} \mathrm{NMR} \mathrm{(100} \mathrm{MHz,} \mathrm{CDCl}_{3}\right) \delta 169.25,163.75$, 152.55, 150.97, 149.80, 147.87, 138.68, 135.14, 133.96, 132.00, 129.93, 129.90, 129.21, 128.82, 
128.41, 126.84, 126.79, 125.15, 124.16, 121.33, 119.04, 112.67, 108.86, 104.33, 97.57, 83.01, 52.98, 44.52, 12.49; IR (thin film)vmax 3450, 2918, 2113, 1751,1419, 1343, 1143, 1049, 811, 745; HRMS-ESI (m/z) [M + H] ${ }^{+}$calcd for $\mathrm{C}_{32} \mathrm{H}_{26} \mathrm{ClN}_{4} \mathrm{O}_{5}{ }^{+}$, 581.1513, found: 581.1523 .

Synthesis of MCR<smiles>CCN(CC)c1ccc2c(c1)Oc1cc(O)c(Cl)cc1C21OC(=O)c2ccccc21</smiles><smiles>Cc1ccccc1C(=O)OCCCCC(C)(C)C</smiles><smiles></smiles>

A solution of 2-methylbenzoyl acid (194.6 mg, $1.43 \mathrm{mmol})$ in DCM (5 mL), was added EDCI (341.5 mg, $1.78 \mathrm{mmol}$ ), DMAP (72.5 mg, $0.59 \mathrm{mmol}$ ) and 7'-chloro- $N, N$-diethylrhodol (500.0 mg, $1.19 \mathrm{mmol})$. The resulting mixture was warmed to room temperature and stirred for $12 \mathrm{~h}$. The resulting solution was poured into water $(30 \mathrm{~mL})$ and extracted with DCM $(3 \times 20 \mathrm{~mL})$. Combined organic layers were washed with brine, dried over anhydrous $\mathrm{MgSO}_{4}$ and concentrated to afford orange oil. Flash chromatography of the crude product (5:1 petroleum ether:ethyl acetate) provided the desired product as a colorless oil (250.0 mg, 39\%). Data for MCR: $\mathrm{R}_{f} 0.35$ (petroleum ether:ethyl acetate $=5: 1) ;{ }^{1} \mathrm{H}$ NMR $\left(400 \mathrm{MHz}, \mathrm{CDCl}_{3}\right) \delta 8.24(\mathrm{~d}, J=7.9 \mathrm{~Hz}, 1 \mathrm{H}), 8.05$ - 8.02 (m, 1H), 7.71 (td, $J=7.5,1.2 \mathrm{~Hz}, 1 \mathrm{H}$ ), 7.65 (dd, $J=7.5,1.0 \mathrm{~Hz}, 1 \mathrm{H}$ ), 7.50 (dd, $J=7.5,1.3$ Hz, 1H), 7.35 (t, $J=8.0 \mathrm{~Hz}, 2 \mathrm{H}), 7.24$ (d, $J=6.7 \mathrm{~Hz}, 2 \mathrm{H}), 6.87$ (s, 1H), 6.57 (d, $J=8.9 \mathrm{~Hz}, 1 \mathrm{H})$, 6.45 (d, $J=2.5 \mathrm{~Hz}, 1 \mathrm{H}), 6.38$ (dd, $J=9.0,2.6 \mathrm{~Hz}, 1 \mathrm{H}), 3.36$ (q, $J=7.0 \mathrm{~Hz}, 4 \mathrm{H}), 2.68$ (s, 3H), 1.18 $(\mathrm{t}, J=7.0 \mathrm{~Hz}, 6 \mathrm{H}) ;{ }^{13} \mathrm{C} \mathrm{NMR}\left(100 \mathrm{MHz}, \mathrm{CDCl}_{3}\right) \delta 169.23,164.30,152.54,152.49,150.89$, 149.73, 148.20, 141.77, 135.06, 133.20, 131.99, 131.47, 129.86, 129.08, 128.77, 127.41, 126.87, 126.02, 125.07, 124.12, 121.48, 118.69, 112.70, 108.76, 104.34, 97.52, 83.03, 44.47, 21.84, 12.44; HRMS-ESI (m/z) [M + H] ${ }^{+}$calcd for $\mathrm{C}_{32} \mathrm{H}_{27} \mathrm{ClNO}_{5}{ }^{+}$, 540.1572, found: 540.1571 . 


\subsection{General procedure for the spectra measurement}

\section{General Procedure for $\mathrm{H}_{2} \mathrm{O}_{2}$ Detection}

All UV-vis, fluorescence, and quantum yield measurements were carried out in $10 \mathrm{mM}$ PBS buffer solution containing $5 \% \mathrm{CH}_{3} \mathrm{OH}$, pH 7.4. In a $5 \mathrm{~mL}$ tube, PBS buffer (4 mL) and ACR (250 $\mu \mathrm{L}, 100 \mu \mathrm{M}$ in $\left.\mathrm{CH}_{3} \mathrm{OH}\right)$ were mixed, and then $\mathrm{H}_{2} \mathrm{O}_{2}$ solution $(50 \mu \mathrm{L}, 4 \mathrm{mM}, 80$ eq) was added. The final solution volume was adjusted to $5 \mathrm{~mL}$ with PBS buffer to obtain a final concentration of $5 \mu \mathrm{M}$. After rapid mixing of the solution, it was placed for 120 min then transferred to a $10 \times 10$ mm quartz cell and incubated at $37{ }^{\circ} \mathrm{C}$ for in vitro detection. Fluorescence spectra were recorded in the range from 560 to $700 \mathrm{~nm}$ with $\lambda_{\mathrm{ex}}=470 \mathrm{~nm}$, and absolute emission quantum yields were determined accordingly.

\section{Preparation of ROS and RNS}

$\mathrm{H}_{2} \mathrm{O}_{2}, t \mathrm{BuOOH}, \mathrm{NaClO}, \mathrm{NaNO}_{2}, \mathrm{NaNO}_{3}, \mathrm{Na}_{2} \mathrm{~S}, \mathrm{Cys}, \mathrm{Hcy}, \mathrm{GSH}, \mathrm{Na}_{2} \mathrm{~S}_{2} \mathrm{O}_{3}, \mathrm{KF}$, NaBrwere prepared from the source of their respective salts or solutions in MeOH/PBS buffer, $10 \mathrm{mM}, \mathrm{pH}=$ 7.4, 5/95.

\section{t-BuOO•}

t-BuOO• was generated from 2,2'-azobis(2-amidinopropane)dihydrochloride (108.5 mg, CAS: 2997-92-4), whichwas dissolved in HEPESbuffer (10 mL,pH7.2) and then $t$-BuOH (36 mg) was added. Then $50 \mu \mathrm{L}$ of this solution was immediately added to $2 \mathrm{~mL}$ HEPES solution containingACR $(250 \mu \mathrm{M})$. The resulting solution was diluted to $5 \mathrm{~mL}$ with HEPES buffer.

\section{ONOO $^{-}$}

The synthesis of peroxynitriteby the additionNaNO${ }_{2}$ to a solution of $\mathrm{H}_{2} \mathrm{O}_{2}$ and $\mathrm{HCl}$ in HEPES 
buffer (pH 7.2). $\mathrm{NaNO}_{2}(5 \mathrm{~mL}, 0.6 \mathrm{M})$ was added to a solution of $\mathrm{H}_{2} \mathrm{O}_{2}(0.6 \mathrm{M})$ and $\mathrm{HCl}(0.7 \mathrm{M})$ in HEPES buffer at $0{ }^{\circ} \mathrm{C}$. $\mathrm{MnO}_{2}(50 \mathrm{mg})$ was added to consume the surplus $\mathrm{H}_{2} \mathrm{O}_{2}$ and then filtered. The resulting solution was kept at $-20^{\circ} \mathrm{C}$. The peroxynitrite concentration was determined to be 170 mMby using an extinction coefficient of $1670 \pm 50 \mathrm{~cm}^{-1}(\mathrm{~mol} / \mathrm{L})^{-1}$ at $302 \mathrm{~nm}$. Then $12 \mu \mathrm{L}$ of this solution was immediately added to $2 \mathrm{~mL}$ HEPES solution containing ACR (250 $\mu \mathrm{M})$. The resulting solution was diluted to $5 \mathrm{~mL}$ with HEPES buffer.

\section{OH•}

Hydroxyl radicals was generated by the addition of $\mathrm{FeSO}_{4}$ and $\mathrm{H}_{2} \mathrm{O}_{2}$ at room temperature in HEPES buffer (pH 7.2) and the mixture was then stirred for 30 min.FeSO $_{4}(4 \mathrm{~mL}, 100 \mathrm{mM})$ and $\mathrm{H}_{2} \mathrm{O}_{2}$ (4 mL, 100mM) was added to HEPES solution, which was diluted to $10.0 \mathrm{~mL}$. Then $50 \mu \mathrm{L}$ of this solution was immediately added to $2 \mathrm{~mL}$ HEPES solution containing ACR $(250 \mu \mathrm{M})$. The resulting solution was diluted to $5 \mathrm{~mL}$ with HEPES buffer.

$$
\mathbf{O}_{2}^{\cdot-}
$$

Superoxide radicalwas prepared from the source of $\mathrm{KO}_{2}$ at room temperature in HEPES buffer (pH 7.2). $\mathrm{KO}_{2}$ (28 mg) was added to absolute DMSO (1 mL). The solution was diluted to $10.0 \mathrm{~mL}$ with HEPES solution after $10 \mathrm{~min}$. Then $50 \mu \mathrm{L}$ of this solution was immediately added to $2 \mathrm{~mL}$ HEPES solution containing ACR $(250 \mu \mathrm{M})$. The resulting solution was diluted to $5 \mathrm{~mL}$ with HEPES buffer.

\section{Quantum Yields}

Fluorescence quantum yields of ACR was determined in PBS buffer (10 mM, pH 7.4) with rhodamine B ( $\Phi=0.89$, in ethanol) as a reference. 7'-Chloro- $N, N$-diethylrhodol was obtained in the experiment by addition of 80 eq of $\mathrm{H}_{2} \mathrm{O}_{2}$ to the solution of probe ACR. The quantum yields 
were calculated using an Eq follows:

$$
\Phi_{\mathrm{u}}=\left[\left(\mathrm{A}_{\mathrm{s}} \mathrm{FA}_{\mathrm{u}} \eta^{2}\right) /\left(\mathrm{A}_{\mathrm{u}} \mathrm{FA} \mathrm{A}_{\mathrm{s}} \eta_{0}{ }^{2}\right)\right] \Phi_{\mathrm{s}} .
$$

Where $A_{s}$ and $A_{u}$ are the absorbance of the reference and sample solution at the reference excitation wavelength, $\mathrm{FA}_{\mathrm{s}}$ and $\mathrm{FA}_{\mathrm{u}}$ are the corresponding integrated fluorescence intensity, and $\eta$ and $\eta 0$ are the solvent refractive indexes of sample and reference, respectively. Absorbance of sample and reference at their respective excitation wavelengths was controlled to be lower than 0.05 .

Quantum yield of ACR: $\Phi=0.0122$

Quantum yield of $\mathbf{A C R}+\mathrm{H}_{2} \mathrm{O}_{2}: \Phi=0.8978$

\section{Detection limit}

To determine the detection limit, the emission intensity of probe ACR without $\mathrm{H}_{2} \mathrm{O}_{2}$ was measured by 10 times and the standard deviation of blank measurements was determined. The detection limit was then calculated with the equation: detection limit $=3 \sigma / k$, where $\sigma$ was the standard deviation of blank measurements, $\mathrm{k}$ was the slope between intensity difference versus sample concentration. According to fluorometric method, the detection limit of probe ACR for $\mathrm{H}_{2} \mathrm{O}_{2}$ was determined as $0.2650 \mu \mathrm{M}$.

Detection limit of $\mathbf{A C R}=0.06473 * 0.021578925 / 0.2443=0.2650$

\subsection{MTT assay}

The MTT assay was used to evaluate the cytotoxicity of probe. MCF-7 cells and 3T3 cells were cultured in DMEM medium supplemented with $10 \%$ fetal bovine serum at $37^{\circ} \mathrm{C}$ in an atmosphere containing 5\% $\mathrm{CO}_{2}$. MCF-7 cells and 3T3 cells were seeded onto 96-well plates at a density of $1 \times 104$ cells/well and incubated for $24 \mathrm{~h}$. The medium was replaced by various probe over a range 
of concentrations $(0.5 \mu \mathrm{M}$ to $30 \mu \mathrm{M})$ dissolved in culture medium. After incubation at $37^{\circ} \mathrm{C}, 5 \%$ $\mathrm{CO}_{2}$ for $24 \mathrm{~h}$, each well of cells were treated with $20 \mu \mathrm{l}$ MTT solution $(5 \mathrm{mg} / \mathrm{mL})$, and incubated for another $4 \mathrm{~h}$. After that, the medium was removed, and $100 \mu \mathrm{L}$ of DMSO were added to dissolve the formazan crystals. The plate was agitated for $10 \mathrm{~min}$, and each well was finally analyzed by the microplate reader (Thermo Scientific, Multiskan FC) and detected by the absorbance at $570 \mathrm{~nm}$.

MCF-7: $\mathrm{IC}_{50} 69.6 \mu \mathrm{M}$.

\subsection{Cell culture and fluorescence imaging}

The Hela cells were cultured in DMEM medium supplemented with $10 \%$ fetal bovine serum at $37^{\circ} \mathrm{C}$ in an atmosphere containing $5 \% \mathrm{CO}_{2}$. For live cell imaging, probe ACR was added to the cells and incubated for 15 min and washed with PBS (phosphate-buffered saline) three times. After replacement of the medium, cells were imaged using an Olympus (FV1000) confocal laser scanning microscope with a $200 \times$ objective lens.

\section{Results and discussion}

\subsection{Design and synthesis}

Taken an overall view of the developed $\mathrm{H}_{2} \mathrm{O}_{2}$ probes, it was obviously that the oxidability of $\mathrm{H}_{2} \mathrm{O}_{2}$ was deeply exploited. For example, the most usedH $\mathrm{H}_{2} \mathrm{O}_{2}$-responsive site,boronate responded to $\mathrm{H}_{2} \mathrm{O}_{2}$ by a chemospecific oxidation of the boronatetophenol [12].However, few of these $\mathrm{H}_{2} \mathrm{O}_{2}$ probeswere based on the nucleophilicity of $\mathrm{H}_{2} \mathrm{O}_{2}$. In fact, developing probes for $\mathrm{H}_{2} \mathrm{O}_{2}$ basedon a non-oxidative mechanism wouldallow the highly specific detectionof $\mathrm{H}_{2} \mathrm{O}_{2}$ under the complicated oxidative circumstancesfound in biological systems.A lotof evidence showed that the nucleophilicity of $\mathrm{H}_{2} \mathrm{O}_{2}$ is just as significant as its oxidability[12,19,20]. Even in the oxidation of 
the boronate, $\mathrm{H}_{2} \mathrm{O}_{2}$ acts as a nucleophile firstly[32]. So it is important to construct a fluorescent probe for $\mathrm{H}_{2} \mathrm{O}_{2}$ based on its nucleophilicity.In fact, it is challenging to design a $\mathrm{H}_{2} \mathrm{O}_{2}$ probe based on its nucleophilicity opposite the interference of many ROSs. However, the nucleophilicity of $\mathrm{H}_{2} \mathrm{O}_{2}$ is different from those of the ROSs after all. Therefore, it may be a feasible strategy for designing a $\mathrm{H}_{2} \mathrm{O}_{2}$ probe by linking an ester bond to a fluorophore.During screening for hydrogen sulfide fluorescent probes, a compound we named ACR $\{6$ '-[2-(azidomethyl)benzoyl]-7'-chloro- $N, N$-diethylrhodol $\}$ was synthesized by the reaction of 7'-chloro- $N, N$-diethylrhodol and 2-(azidomethyl)benzoyl acid (scheme 1). However, ACR did not respond to $\mathrm{H}_{2} \mathrm{~S}$ at all, but triggered obvious fluorescence enhancement to $\mathrm{H}_{2} \mathrm{O}_{2}$. Considering the nucleophilicity of $\mathrm{H}_{2} \mathrm{O}_{2}$, the detection of $\mathrm{H}_{2} \mathrm{O}_{2}$ by ACR was based on anon-oxidative mechanism. And ACR responded to $\mathrm{H}_{2} \mathrm{O}_{2}$ by a nucleophilic substitution of the ester bond.

\subsection{Sensing properties of probe ACR}

ACR exhibited almost no fluorescence (fluorescence quantum yield: $\Phi=0.0122$, in $\mathrm{CH}_{3} \mathrm{OH} / \mathrm{PBS}$ buffer, $10 \mathrm{mM}, \mathrm{pH}=7.4,5 / 95$ ). To verify the selectivity of ACR for $\mathrm{H}_{2} \mathrm{O}_{2}$, the fluorescence changes of $\mathbf{A C R}(5 \mu \mathrm{M})$ were examined upon addition of $\mathrm{H}_{2} \mathrm{O}_{2}$ (80 equiv) and other ROS (peroxynitrite, superoxide radical,nitrate radical, $t \mathrm{BuOOH}$, hydroxy radical, $\mathrm{NaOCl}$, and so on) in PBS for 0-120 min (Fig. 1A). As shown in Fig. 1A, $\mathrm{H}_{2} \mathrm{O}_{2}$ could trigger obvious fluorescent increments while other ROSs showed a negligible fluorescence response with ACR. tBuOO could also lead to small fluorescence enhancement. As shown in Fig. 1B, the relative enhancement of fluorescence caused by $t \mathrm{BuOO}$ - was 3.4-fold, which was much lower than that of $\mathrm{H}_{2} \mathrm{O}_{2}$ (127-fold,fluorescence quantum yield: $\Phi=0.8978$ ). As an important interferingspecies to 
$\mathrm{H}_{2} \mathrm{O}_{2}$, peroxynitrite even lead a smllerfluorescence enhancement than $t \mathrm{BuOO} \cdot$ Superoxide radicaltriggered a slightly obvious fluorescence enhancement which was still far lower thanthat of $\mathrm{H}_{2} \mathrm{O}_{2}$. Considering ACR was designed for a $\mathrm{H}_{2} \mathrm{~S}$ probe firstly and 2-azidomethylbenzoate had been used as a $\mathrm{H}_{2} \mathrm{~S}$ trap [33]. Although 2-azidomethyl-benzoate connected to an electron rich dye was failed to response to $\mathrm{H}_{2} \mathrm{~S}$, it was still essential to test and verify $\mathrm{H}_{2} \mathrm{~S}$ [34]. $\mathrm{ThenH}_{2} \mathrm{~S}$ and other biologically relevant nucleophilic species were also examined. As a result,probe ACR barely showed little fluorescence enhancement under the same condition (Fig. 1B).

Subsequently, the changes of fluorescence spectra of probeACRincubatedwith various concentrations of $\mathrm{H}_{2} \mathrm{O}_{2}$ were monitored. Fig. 2A showed the fluorescence spectra of probe ACR before and after addition of different amounts of $\mathrm{H}_{2} \mathrm{O}_{2}$. As anticipated, after incubation with $\mathrm{H}_{2} \mathrm{O}_{2}$, the fluorescence intensity increased gradually. Fig. 2B shows the plot of the relative fluorescence intensity (F/F0) at $560 \mathrm{~nm}$ as a function of concentration of $\mathrm{H}_{2} \mathrm{O}_{2}$. The fluorescence intensity of probe ACR increased almost linearly with the concentration of $\mathrm{H}_{2} \mathrm{O}_{2}$ in the range of 0-400 $\mu \mathrm{M}$, and with a correlation coefficient of 0.9987 . Good linear correlation indicated that ACR was able to qualitatively and quantitatively determine the level of $\mathrm{H}_{2} \mathrm{O}_{2}$.

When treated with $\mathrm{H}_{2} \mathrm{O}_{2}$, ACR showed a fluorescent intensity increasing gradually almost linear to the time in $120 \mathrm{~min}$ (Fig. 3). Indeed, the enhancement offluorescence intensity after reaction with $\mathrm{H}_{2} \mathrm{O}_{2}$ was ashigh as 127 -fold. By fitting the data (Figs. 3 and S1, ESI ${ }^{\dagger}$ )with a pseudo-firstordermodel(ACR, $5 \mu$ Mand $\mathrm{H}_{2} \mathrm{O}_{2}, 400 \mu \mathrm{M}$ ), the reactionrate constant was obtained as $5.7 \times 10^{-2} \mathrm{~s}^{-1}$ at $25^{\circ} \mathrm{C}$ (Fig.S2, $\mathrm{ESI}^{\dagger}$ ). This value is comparable to (a little smallerthan) those of previously reported fluorescence probes $\mathrm{forH}_{2} \mathrm{O}_{2}$ based on boronate chemistry [35] and BaeyerVilliger type reaction [22].Specifically, the detection limit of $\mathrm{H}_{2} \mathrm{O}_{2}$ was determined to be 
$0.2650 \mu \mathrm{M}$ based on the $3 \sigma /$ slope method(Fig. S3, $\mathrm{ESI}^{\dagger}$ ), which was much lower than those of the reported probes [12,13]. Perhaps, the specialnon-oxidative detection routeincreased the selectivity toward $\mathrm{H}_{2} \mathrm{O}_{2}$.We then evaluated the effect of $\mathrm{pH}$ on the fluorescence of ACR, which showed it was very stable from $\mathrm{pH} 6$ to 8 , even in the presence of $\mathrm{H}_{2} \mathrm{O}_{2}$ (Fig. S4, $\mathrm{ESI}^{\dagger}$ ).

Next, we performed competition experiments in the presence of ROS and $\mathrm{H}_{2} \mathrm{~S}$ (Fig. 4). ACR was still able to respond to $\mathrm{H}_{2} \mathrm{O}_{2}$ with strong fluorescence enhancements in the coexistence of the interfering species.Although the reactionrate constant of ACR with $\mathrm{H}_{2} \mathrm{O}_{2}$ was a little smallerthanthe previously reported probes, ACRexhibited excellentselectivity to $\mathrm{H}_{2} \mathrm{O}_{2}$. Moreover, the non-oxidative process of ACR for detection of $\mathrm{H}_{2} \mathrm{O}_{2}$ was confirmed by the HRMS-ESI spectra. The peak for 7'-chloro- $N, N$-diethylrhodol (calcd for $[\mathrm{M}+\mathrm{H}]^{+}\left[\mathrm{C}_{24} \mathrm{H}_{21} \mathrm{ClNO}_{4}\right]^{+}, 422.1154$, found: 422.1140, Fig. S5, ESI $\dagger$ ), was detected after probe ACR was reacted with $\mathrm{H}_{2} \mathrm{O}_{2}$.

To further prove the selectivity of probe ACR for $\mathrm{H}_{2} \mathrm{O}_{2}$, time-dependent fluorescence changes over ROS and $\mathrm{H}_{2} \mathrm{~S}$ were recorded. As shown in Fig. 5, the fluorescence enhancements for other ROS and $\mathrm{H}_{2} \mathrm{~S}$ were still negligible until 120 min. More importantly, the fluorescent intensity for $\mathrm{H}_{2} \mathrm{O}_{2}$ was increased obviously to the time, while the increment for other ROS and $\mathrm{H}_{2} \mathrm{~S}$ almost ceased. Thus, the interference of other ROS and $\mathrm{H}_{2} \mathrm{~S}$ was negligible, and probe ACR showed high selectivity toward $\mathrm{H}_{2} \mathrm{O}_{2}$.

\subsection{Exploring the effect of chlorine and azide}

The detection mechanism of probe ACR was very attractive for its special non-oxidative route, which would allow the high specificdetectionof $\mathrm{H}_{2} \mathrm{O}_{2}$ under complicated oxidative circumstancesfound in biological systems [19]. Although it was believed that anucleophilic 
substitution reaction was happened during the detection, the effect of every functional group was still unclear. In fact, we have not been fully understood the nucleophilicityof $\mathrm{H}_{2} \mathrm{O}_{2}$ which hindered deep studying.A deep study was conducted for understanding the nucleophilicity of $\mathrm{H}_{2} \mathrm{O}_{2}$. To further explore the relationship of the chlorine atom, azide group and the activity of the carbonyl, two other compoundsAR[34] and MCR were synthesized and investigated. Both AR and MCR showed little response when treated with $\mathrm{H}_{2} \mathrm{O}_{2}$ or other ROS, even reactive sulfurspecies (RSS).The results kept the same even in 120 min (Scheme 2, Figs. S6 and S7, ESI ${ }^{\dagger}$ ). In other words, only the ester bond in ACR was able to be broken by $\mathrm{H}_{2} \mathrm{O}_{2}$, and this bond was only able broken by $\mathrm{H}_{2} \mathrm{O}_{2}$. The results showed that probe ACR was made up of three essential parts, chlorine atom and azide group, whichform an active carbonyl.

\subsection{Detection of $\mathrm{H}_{2} \mathrm{O}_{2}$ in living cells}

Encouraged by the above results, we subsequently assessed the potential applications of ACR for monitoring and imaging of $\mathrm{H}_{2} \mathrm{O}_{2}$ in living cells. Firstly, the cytotoxicity of ACR was evaluated using A-549 cells and Raw 264.7 cells by MTT assay [3-(4,5-dimethylthiazol-2-yl)-2,5-diphenyltetrazolium bromide, Fig. S8, ESI ${ }^{\dagger}$. Probe ACR showed almost no cytotoxicity in the $0.1-30 \mu \mathrm{M}$ range to both of them, implying that the probe was suitable for bioimaging of $\mathrm{H}_{2} \mathrm{O}_{2}$ in living cells. Hela cells incubated with ACR (10 $\left.\mu \mathrm{M}\right)$ in culture medium for $15 \mathrm{~min}$ at $37^{\circ} \mathrm{C}$, showed almost no fluorescence (Fig. 6B). Fig. 6A is the bright-field image. Fig. 6C is the overlay of the Figs.6A and B. However, if Hela cells were pretreated with ACR $(10 \mu \mathrm{M})$ for 15 min and then incubated with $\mathrm{H}_{2} \mathrm{O}_{2}(25 \mu \mathrm{M})$ for $15 \mathrm{~min}$, strong fluorescence was observed (Fig. 6D). This result indicates that probe ACR has the potential 
to visualize $\mathrm{H}_{2} \mathrm{O}_{2}$ levels in living cells. Fig. 6E is the overlay of the Figs. 6D and F (bright-field image). The obvious fluorescent increments indicated that the probe could image of the exogenous $\mathrm{H}_{2} \mathrm{O}_{2}$.

\section{Conclusion}

In summary, aiming at finding high-selectivity fluorescent probes for detection of $\mathrm{H}_{2} \mathrm{O}_{2}$, a new probe ACR was designed and synthesized. Probe ACR was proved to be made up of three essential parts, chlorine atom, azide group and an active carbonyl,due to the special nucleophilicity of $\mathrm{H}_{2} \mathrm{O}_{2}$. This probe showed high selectivity for $\mathrm{H}_{2} \mathrm{O}_{2}$ and a linear fluorescence intensity enhancement with a wide range of concentrations of $\mathrm{H}_{2} \mathrm{O}_{2}$. Preliminary fluorescence imaging experiments in HeLa cells indicated its potential to image $\mathrm{H}_{2} \mathrm{O}_{2}$ in biological systems(endogenous levels of $\mathrm{H}_{2} \mathrm{O}_{2}$ are reported to be less than $100 \mathrm{uM}$ ) [25].Relevant studies on this strategy and its biological applications are underway.

\section{Acknowledgements}

Funding was partially provided by the National Science Foundation of China (21402064), the startup fund of University of Jinan,the Doctoral Fund of University of Jinan (160080304) and the Science Foundation for Post Doctorate Research from the University of Jinan (1003814). 


\section{Reference}

1. S. X. Chen, P. Schopfer, Eur. J. Biochem. 260 (1999) 726 -735.

2. R. S. Balaban, S. Nemoto and T. Finkel, Cell 120 (2005) 483-495.

3. S. G. Rhee, Science312 (2006) 1882-1883.

4. H. A. Woo, S. H. Yim, D. H. Shin, D. Kang, D.-Y. Yu, S. G. Rhee, Cell 140 (2010) 517-528.

5. J. D. Lambeth, Nat. Rev. Immunol. 4 (2004) 181-189.

6. M. T. Lin, M. F. Beal, Nature 443 (2006) 787-795.

7. J. Andersen, Nat. Rev. Neurosci. 10 (2004) S18-S25.

8. M. P. Mattson, Nature 430 (2004) 631-639.

9. H. Ohshima, M. Tatemichi, T. Sawa, Arch. Biochem. Biophys. 417 (2003) 3-11.

10. H. M. Cocheme, A. Logan, T. A. Prime, I. Abakumova, C. Quin, S. J. McQuaker, J. V. Patel, I. M. Fearnley, A. M. James, C. M. Porteous, R. A. Smith, R. C. Hartley, L. Partridge, M. P. Murphy, Nat. Protoc. 7 (2012) 946-958.

11. V. V. Belousov, A. F. Fradkov, K. A. Lukyanov, D. B. Staroverov, K. S. Shakhbazov, A. V. Terskikh, S. Lukyanov, Nat. Methods 3 (2006) 281-286.

12. A. R. Lippert, G. C. Van de Bittner, C. J. Chang, Acc. Chem. Res. 44 (2011) 793-804.

13. X. Chen, X. Tian,I. Shin, J. Yoon, Chem. Soc. Rev. 40 (2011) 4783-4804.

14. Y. Urano, M. Kamiya, K. Kanda, T. Ueno, K. Hirose, T. Nagano, J. Am. Chem. Soc. 127 (2005) 4888-4894.

15. N.Karton-Lifshin, E. Segal,L. Omer, M. Portnoy, R.Satchi-Fainaro,D.Shabat, J. Am. Chem. Soc. 133 (2011) 10960-10965.

16. Y. Wen, K. Liu, H. Yang, Y. Li, H. Lan, Y. Liu, X. Zhang, T. Yi, Anal. Chem. 86 (2014) 
9970-9976.

17. W. Zhang, W. Liu, P. Li, F. Huang, H. Wang, B. Tang, Anal. Chem. 87 (2015)9825-9828.

18. M. Ren, B. Deng, K. Zhou, X. Kong, J. Wang, W. Lin, Anal. Chem. 89 (2017) 552-555.

19. H. Maeda, Y. Fukuyasu, S. Yoshida, M. Fukuda, K. Saeki, H. Matsuno, Y. Yamauchi, K. Yoshida, K. Hirata, K. Miyamoto, Angew. Chem. In. Ed. 43 (2004) 2389-2391.

20. H. Li, Q. Li, X. Wang, K. Xu, Z. Chen, X. Gong, X. Liu, L. Tong, B. Tang, Anal. Chem. 81 (2009) 2193-2198.

21. N. Soh, O. Sakawaki, K. Makihara, Y. Odo, T. Fukaminato, T. Kawai, M. Irie, T. Imato, Bioorg. Med. Chem. 13 (2005) 1131-1139.

22. M. Abo, Y. Urano, K. Hanaoka, T. Terai, T. Komatsu, T. Nagano, J. Am. Chem. Soc. 133 (2011) 10629-10637.

23. M. Abo, R. Minakami, K. Miyano, M. Kamiya, T. Nagano, Y. Urano, H.Sumimoto, Anal. Chem. 86 (2014) 5983-5990.

24. K. Zhang, W. Dou, P. Li, R. Shen, J. Ru, W. Liu, Y. Cui, C. Chen, W. Liu, D. Bai,Biosens.Bioelectron. 64(2015)542-546.

25. B. Dong, X. Song, X. Kong, C. Wang, Y. Tang, Y. Liu,W. Lin, Adv. Mater.28 (2016) 8755-8759.

26. A. R. Lippert, T. Gschneidtner, C. J. Chang, Chem. Commun. 46 (2010) 7510-7512.

27. Y.Hitomi,T.Takeyasu, T.Funabiki,M. Kodera, Anal. Chem. 83 (2011) 9213-9216.

28. D. Song,J. M. Lim, S. Cho,S. Park, J. Cho, D. Kang,S. G. Rhee, Y. You, W. Nam, Chem. Commun. 48 (2012) 5449-5451.

29. Y.Hitomi, T.Takeyasu, M. Kodera,Chem. Commun. 49 (2013) 9929-9931. 
30. Y.-X. Liao, K. Li, M.-Y. Wu, T. Wu, X.-Q. Yu, Org.Biomol. Chem. 12 (2014) 3004-3008.

31. M. Kaur, D.S. Yang, K. Choi, M. J. Cho, D. H. Choi, Dyes Pigments100 (2014) 118-126.

32. S. L. Hempel, G. R. Buettner, Y. Q. O’Malley, D. A. Wessels, D. M. Flaherty, Free Radical Biol. Med. 27 (1999) 146-159.

33. Z. Wu, Z. Li, L. Yang, J. Han, S. Han, Chem. Commun. 48 (2012) 10120-10122.

34. Q. Yang, F. Zhan, Q. Wang, Z. Zhuang, G. Zhang, G. Zheng, RSC Adv. 5 (2015) 106156-106160.

35. B. C. Dickinson, C. Huynh, C. J. Chang, J. Am. Chem. Soc. 132 (2010)5906-5915. 


\section{List of Figure Captions}

Scheme 1.Synthesis of probe ACR and the response of ACR to $\mathrm{H}_{2} \mathrm{O}_{2}$.

Scheme 2.Confirmation the effects of chlorine atom and azide groupin probe ACR.

Fig.1.(A) Fluorescence response of ACR $(5 \mu \mathrm{M})$ incubated with $\mathrm{ROS}$ and $\mathrm{H}_{2} \mathrm{O}_{2}$ (80 eq) in $\mathrm{CH}_{3} \mathrm{OH} / \mathrm{PBS}$ buffer $(10 \mathrm{mM}, \mathrm{pH}=7.4,5 / 95)$ for 120 min. (B) Bar graph. 1. Blank,2. $\mathrm{H}_{2} \mathrm{O}_{2}$, 3.tBuOOH, 4. $t \mathrm{BuOO} \bullet$ (in HEPES buffer), 5. $\mathrm{HO} \bullet$ (in HEPES buffer), 6. NaClO, 7. $\mathrm{ONOO}^{-}$(in HEPES buffer), 8. $\mathrm{NaNO}_{2}, 9 . \mathrm{O}_{2}^{--}$(in HEPES buffer), 10. $\mathrm{NaNO}_{3}, 11 . \mathrm{Na}_{2} \mathrm{~S}, 12 . \mathrm{Cys}, 13 . \mathrm{Hcy}$, 14.GSH, 15. $\mathrm{Na}_{2} \mathrm{~S}_{2} \mathrm{O}_{3}$, 16.KF, 17.NaBr, 18.KI. $\lambda_{\mathrm{ex}}=470 \mathrm{~nm}, \lambda_{\mathrm{em}}=560 \mathrm{~nm}$. Slits: $5 / 5 \mathrm{~nm}$.

Fig.2.(A) Fluorescence spectra of ACR $(5 \mu \mathrm{M})$ incubated with different concentrations of $\mathrm{H}_{2} \mathrm{O}_{2}$ (0-200 eq, 0-1.0 mM) in $\mathrm{CH}_{3} \mathrm{OH} / \mathrm{PBS}$ buffer $(10 \mathrm{mM}$, $\mathrm{pH}=7.4,5 / 95)$ for $120 \mathrm{~min}$. (B) Linear fitting chart. $\lambda_{\mathrm{ex}}=470 \mathrm{~nm}, \lambda_{\mathrm{em}}=560 \mathrm{~nm}$. Slits: $5 / 5 \mathrm{~nm}$.

Fig.3. (A) Time-dependent fluorescence spectral changes of ACR (5 $\mu \mathrm{M})$ with $\mathrm{H}_{2} \mathrm{O}_{2}$ (80 eq, 400 $\mu \mathrm{M})$ in $\mathrm{CH}_{3} \mathrm{OH} / \mathrm{PBS}$ buffer $(10 \mathrm{mM}, \mathrm{pH}=7.4,5 / 95)$. (B) Line chart. $\lambda_{\mathrm{ex}}=470 \mathrm{~nm}, \lambda_{\mathrm{em}}=560 \mathrm{~nm}$. Slits: $5 / 5 \mathrm{~nm}$

Fig.4.Fluorescence responses of ACR $(5 \mu \mathrm{M})$ towards $\mathrm{H}_{2} \mathrm{O}_{2}(400 \mu \mathrm{M})$ with various analytes $(400 \mu \mathrm{M})$ in $\mathrm{CH}_{3} \mathrm{OH} / \mathrm{PBS}$ buffer $(10 \mathrm{mM}, \mathrm{pH}=7.4,5 / 95) .1 . \mathrm{H}_{2} \mathrm{O}_{2}$ only;2-10, $\mathrm{H}_{2} \mathrm{O}_{2}$ and indicatedanalyte: 2. $t \mathrm{BuOOH}$, 3. $t \mathrm{BuOO} \bullet($ in HEPES buffer), 4. HO• (in HEPES buffer), 5 . $\mathrm{ONOO}^{-}$(in HEPES buffer), 6.NaNO $2,7.0_{2}^{\circ-}$ (in HEPES buffer), 8.Na 2 S, 9.Cys, 10.Hcy, 11.KF. $\lambda_{\text {ex }}$ $=470 \mathrm{~nm}, \lambda_{\mathrm{em}}=560 \mathrm{~nm}$. Slits: $5 / 5 \mathrm{~nm}$.

Fig.5.Time-dependent fluorescence spectral changes of ACR $(5 \mu \mathrm{M})$ with $\mathrm{ROS}$ and $\mathrm{H}_{2} \mathrm{~S}$ (80 eq for each, $400 \mu \mathrm{M})$ in $\mathrm{CH}_{3} \mathrm{OH} / \mathrm{PBS}$ buffer $(10 \mathrm{mM}, \mathrm{pH}$ = 7.4, 5/95). Time points represent 30, 60, 90, and $120 \mathrm{~min} . \lambda_{\mathrm{ex}}=470 \mathrm{~nm}, \lambda_{\mathrm{em}}=560 \mathrm{~nm}$. Slits: $5 / 5 \mathrm{~nm}$. 
Fig.6.Bright-field (A), fluorescence image (B) and the overlay (C) of Figs. A and B of Hela cells incubated with ACR (10 $\mu \mathrm{M})$ for 15 min. Bright-field (D), fluorescence image (E) and the overlay (F) of Figs. D and E of Hela cells incubated with ACR $(10 \mu \mathrm{M})$ for 15 min and washed with PBS three times. After replacement of the medium, cells were incubated with $\mathrm{H}_{2} \mathrm{O}_{2}(25 \mu \mathrm{M})$ for another 15 min. 


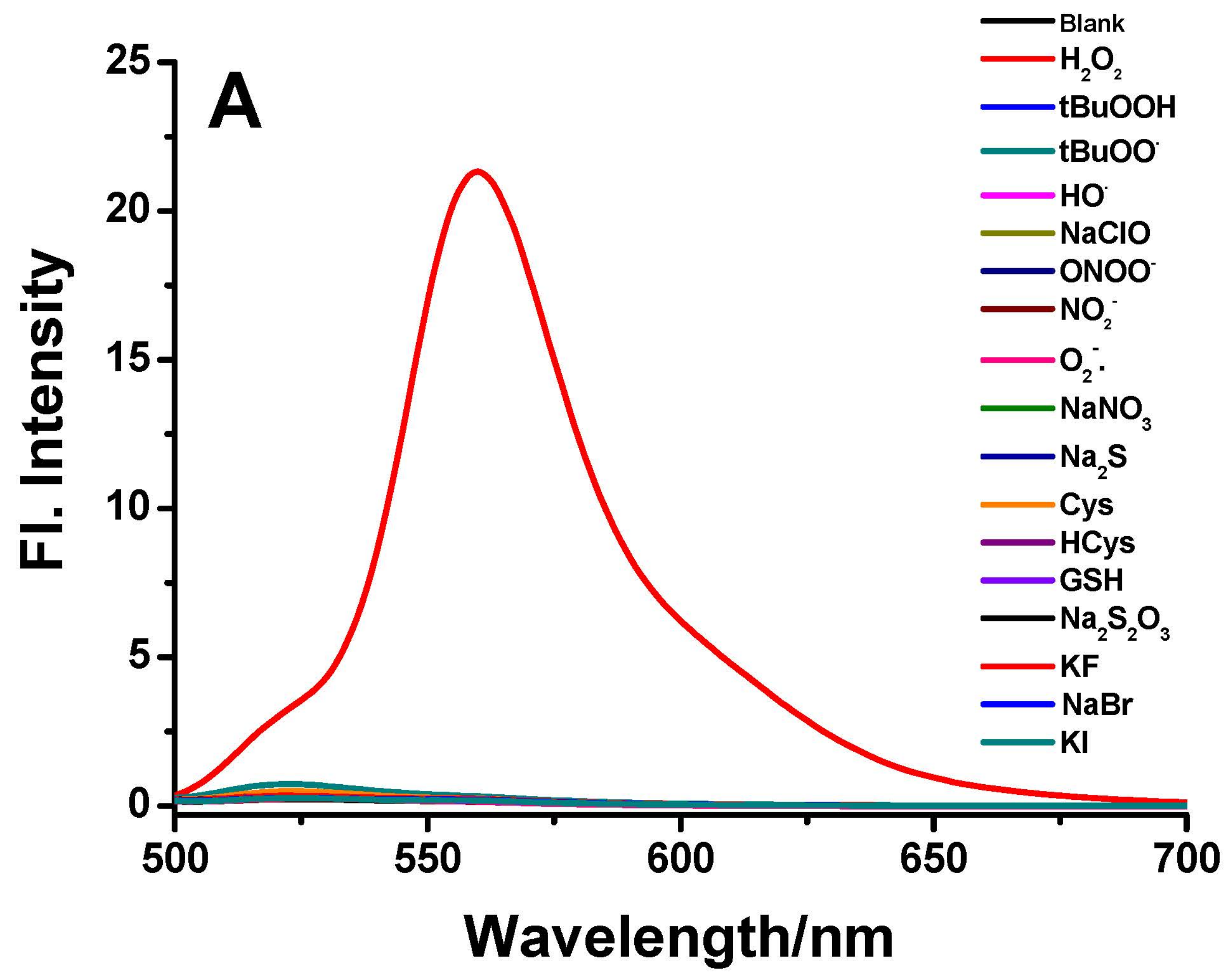




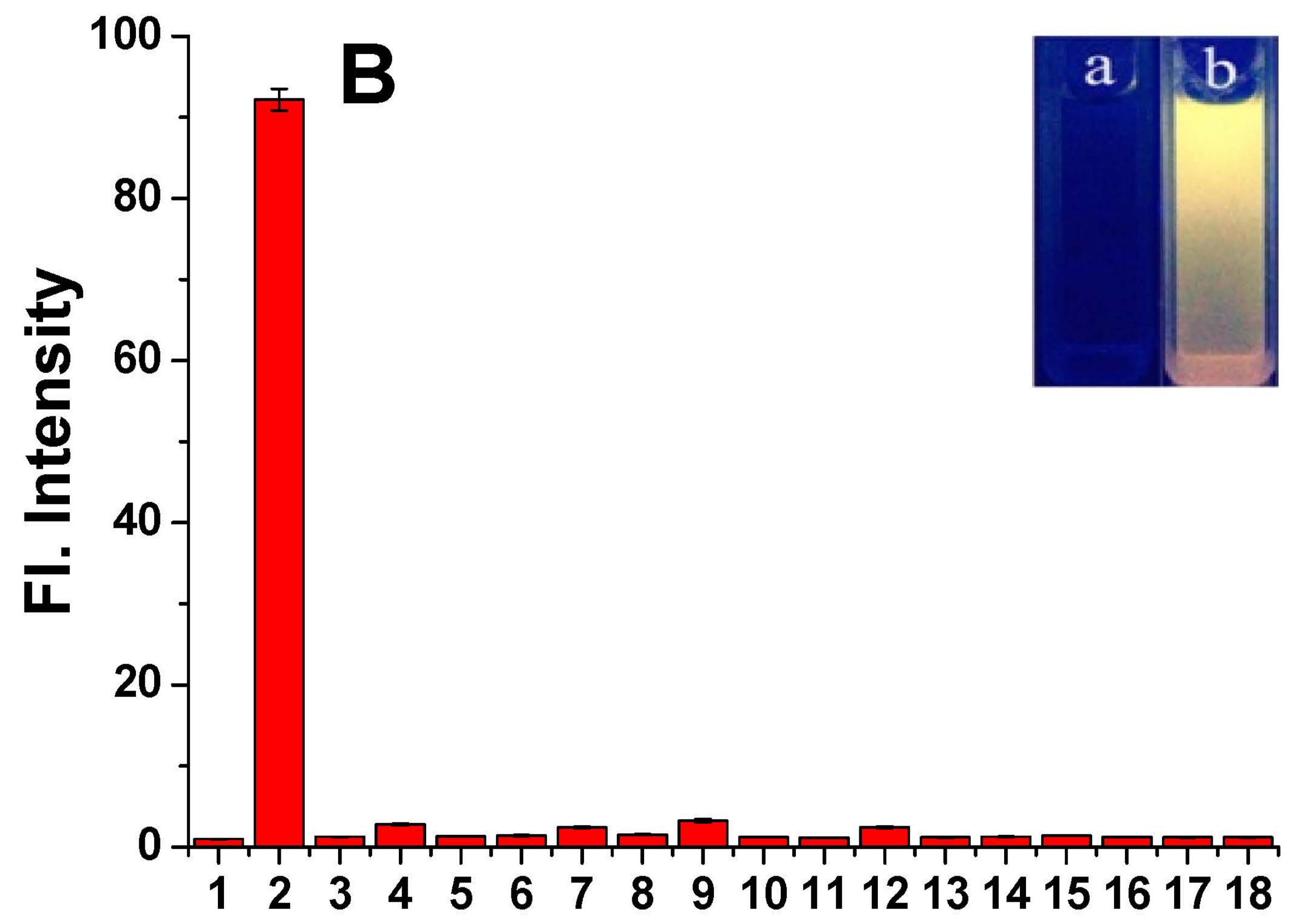




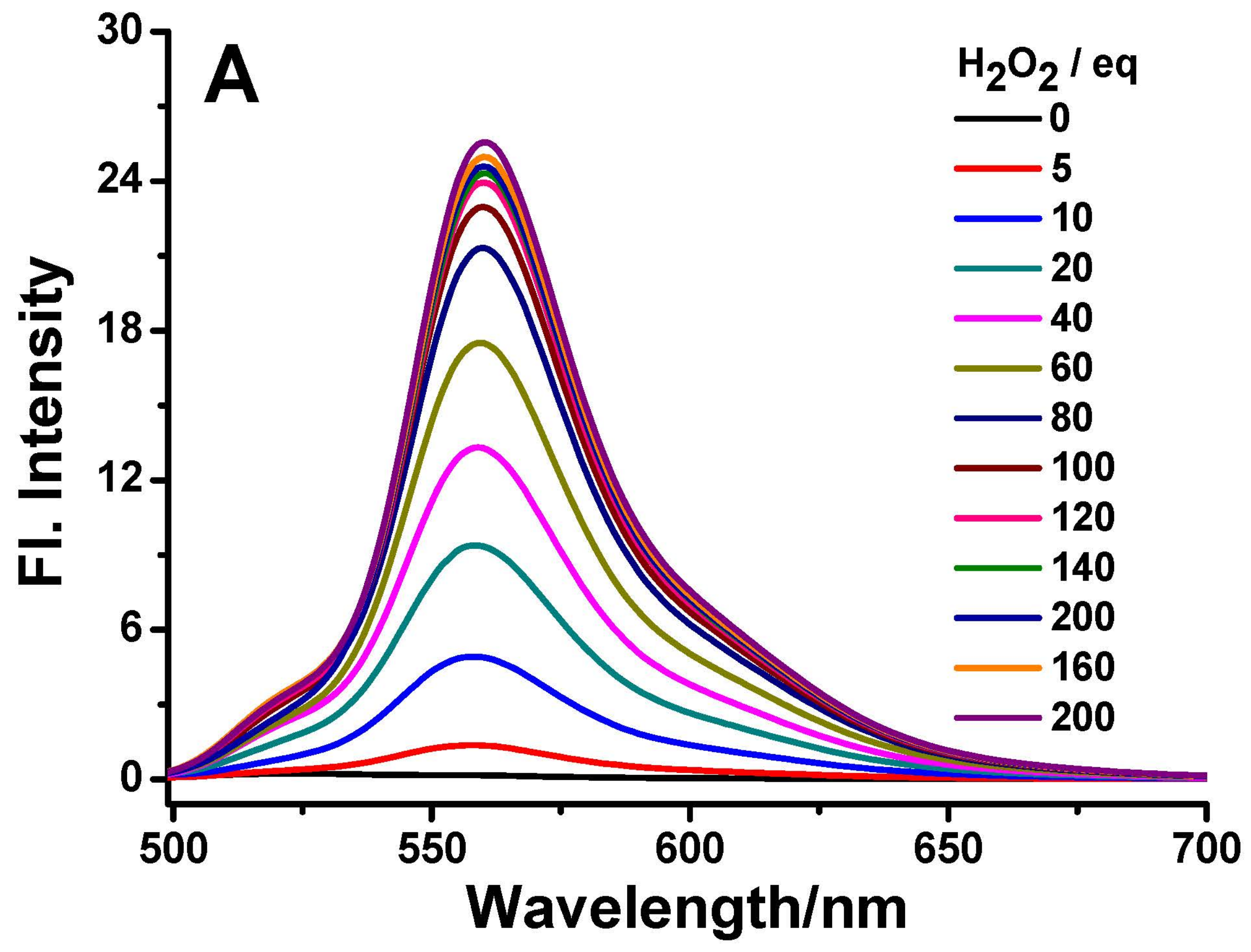




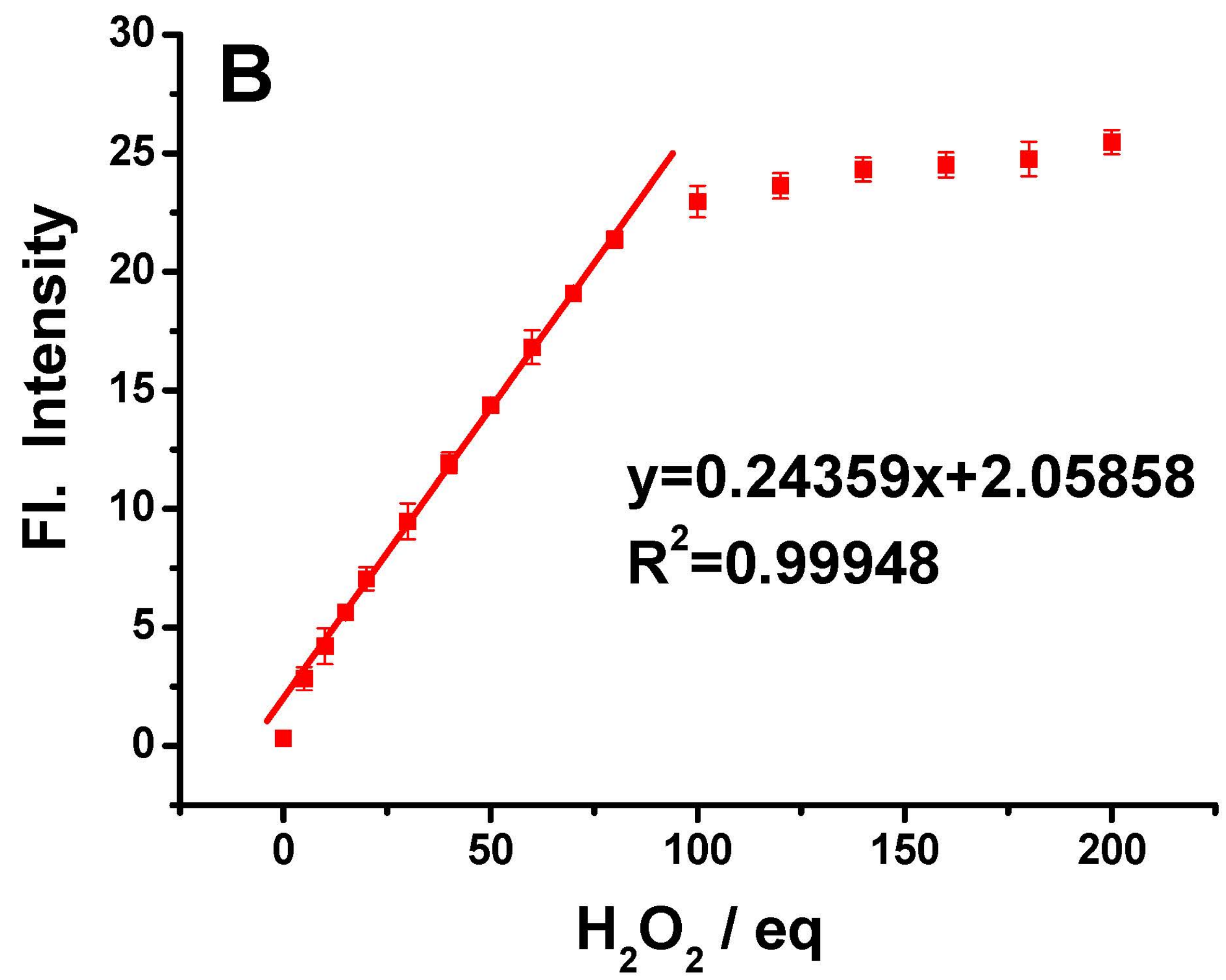




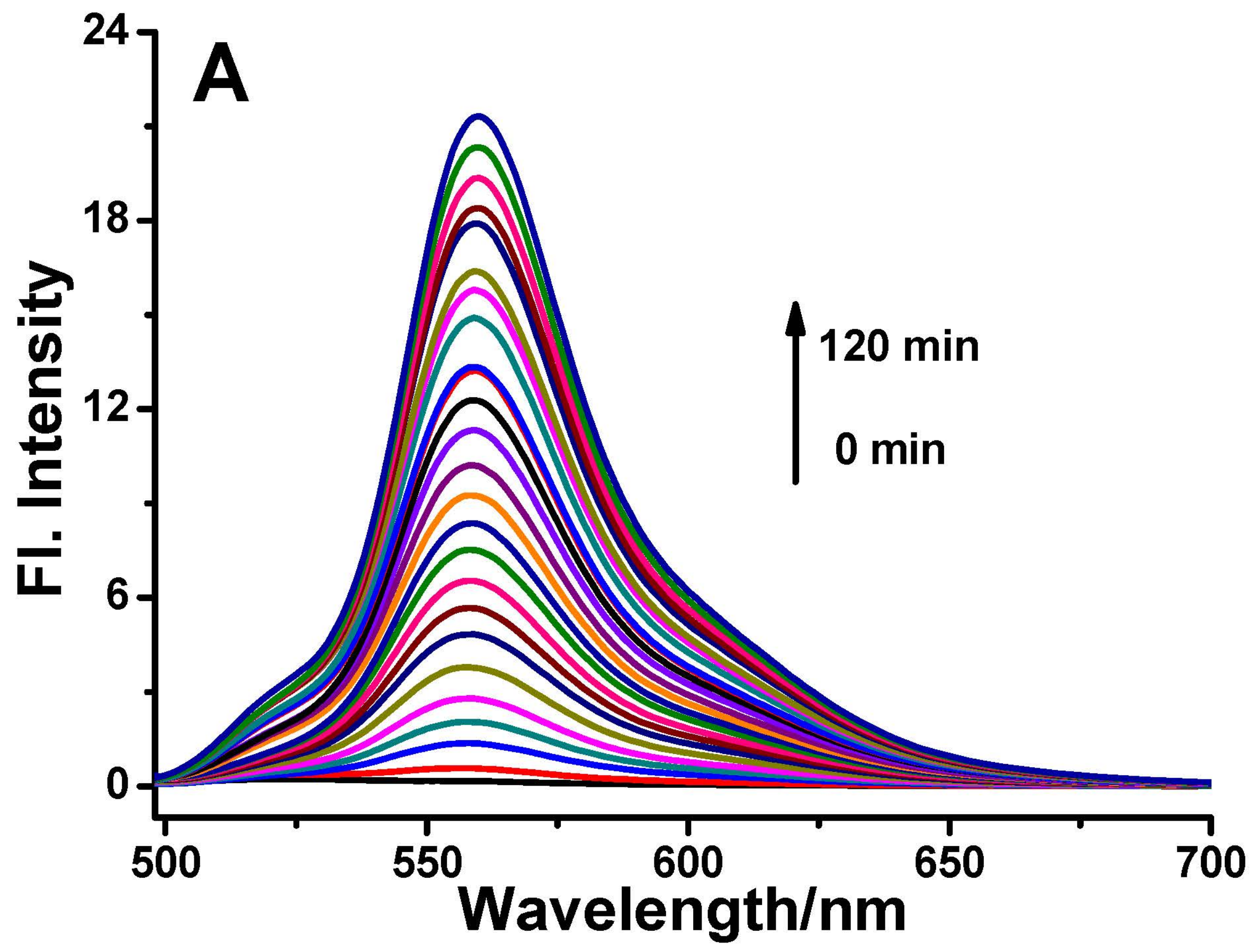




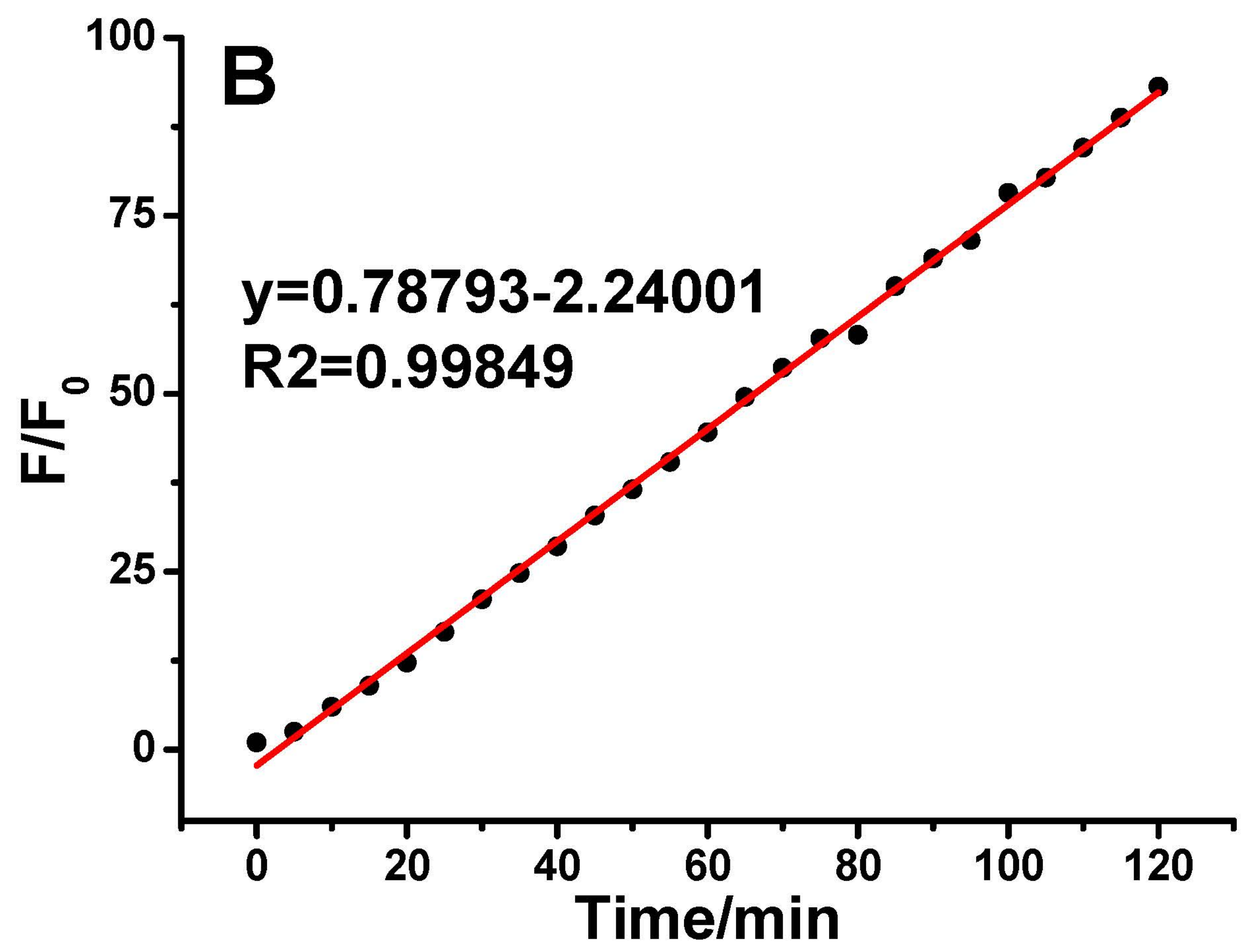




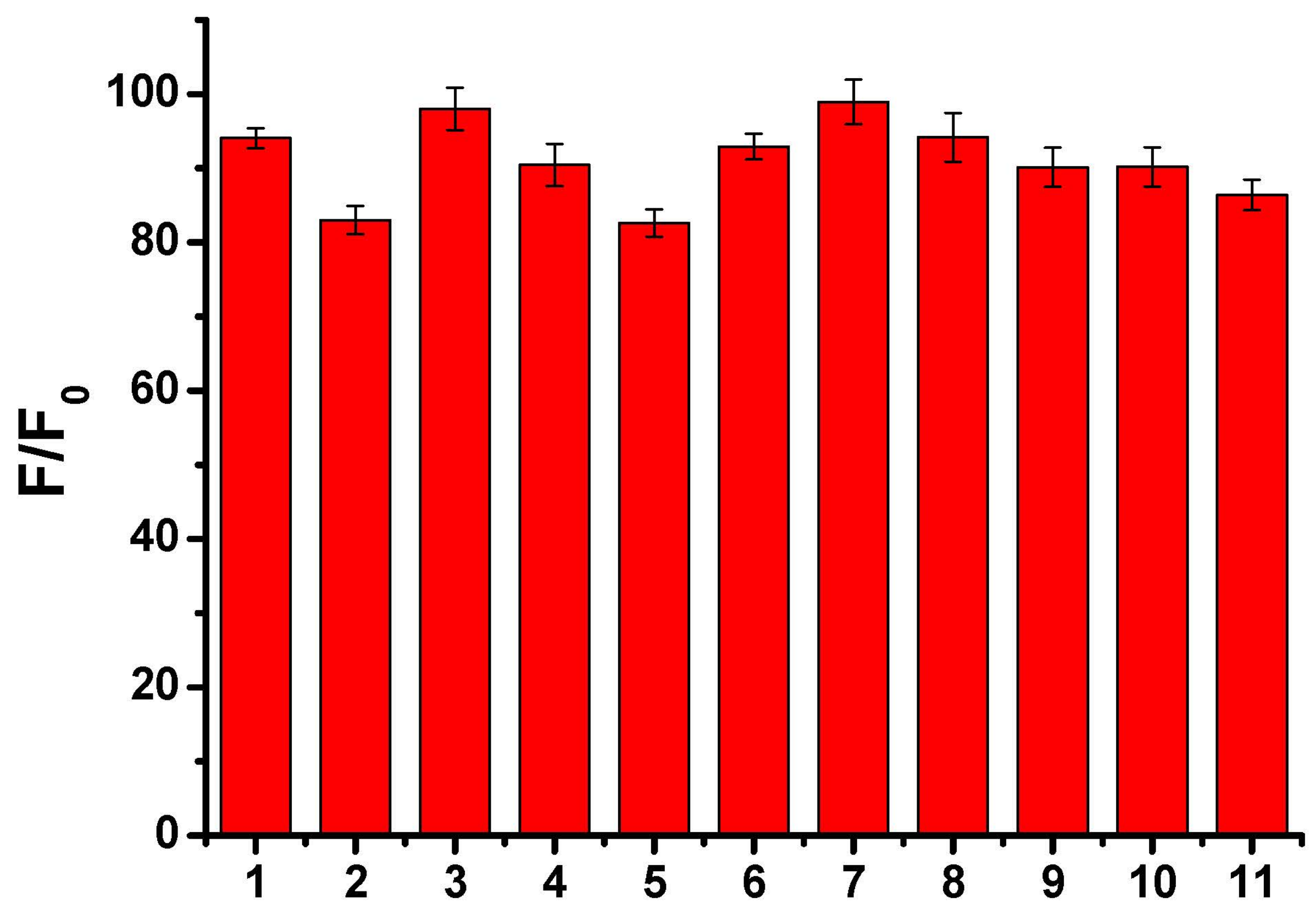




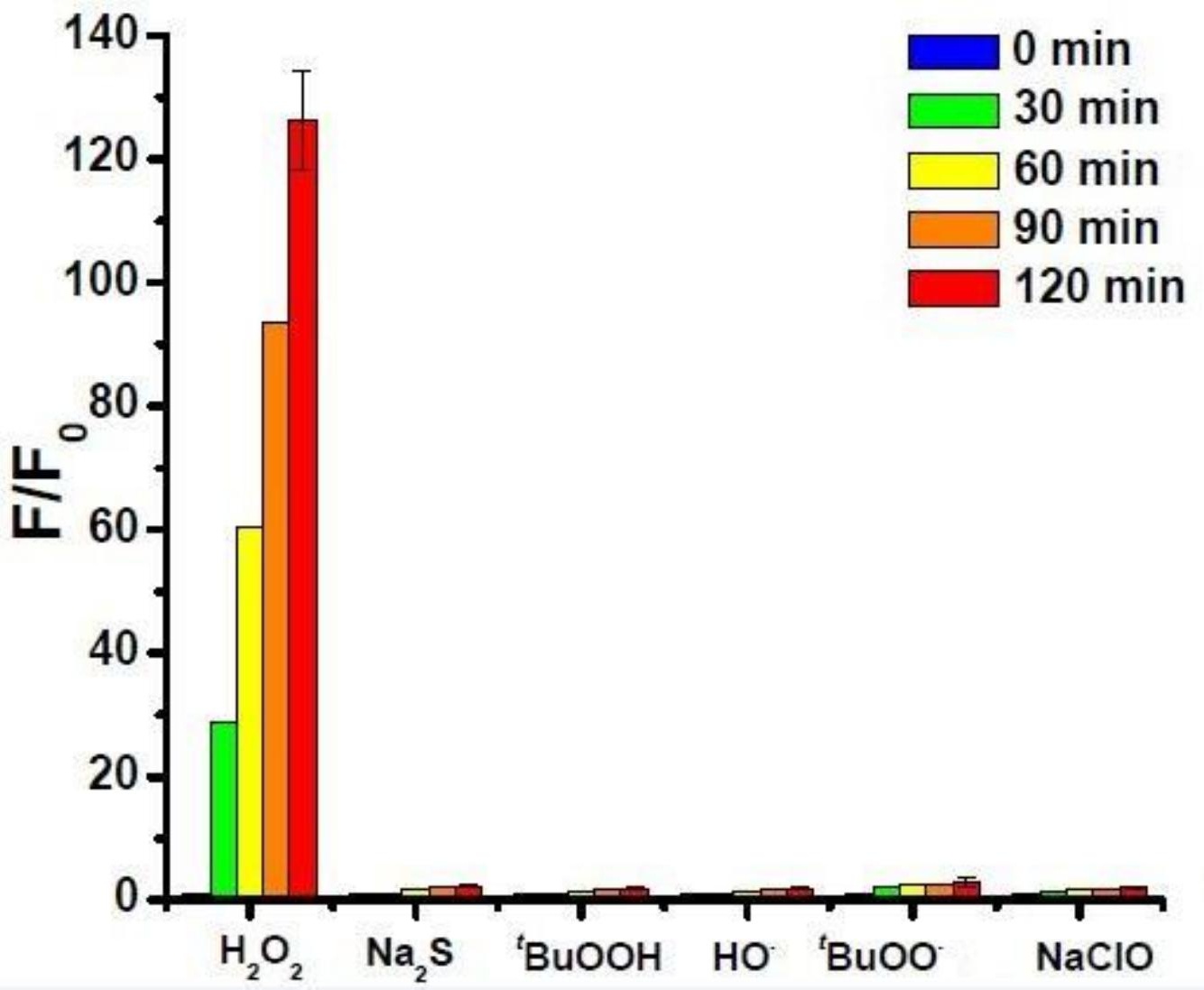




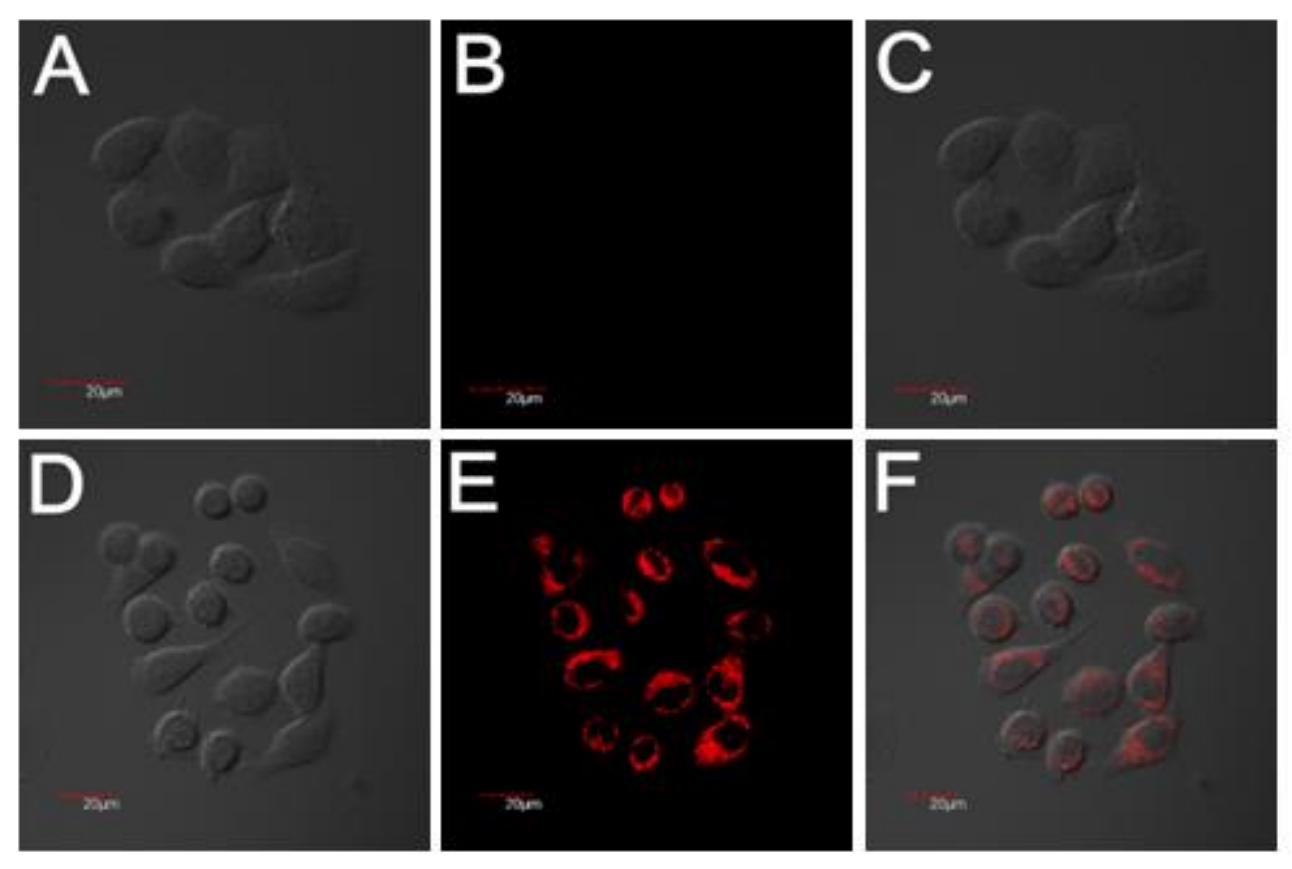



